tolerability and efficacy. In these cases, availability of a sustained-release formulation has benefits beyond the issue of compliance. These benefits may not be present for all drugs, depending on their individual pharmacokinetics.

(C) 2016 American Academy of Neurology

1. French JA, Berg MJ. The place of generic modified-release formulations for epilepsy: slow and steady. Neurology 2016; $86: 1572-1573$.
2. Johnson EL, Chang YT, Davit B, Gidal BE, Krauss GL. Assessing bioequivalence of generic modified-release antiepileptic drugs. Neurology 2016;86:1597-1604.

3. Cramer JA, Mattson RH, Prevey ML, Scheyer RD, Ouellette VL. How often is medication taken as prescribed? A novel assessment technique. JAMA 1989;261: 3273-3277.

4. Cramer J, Vachon L, Desforges C, Sussman NM. Dose frequency and dose interval compliance with multiple antiepileptic medications during a controlled clinical trial. Epilepsia 1995;36:1111-1117.

\title{
CORRECTION
}

\section{Low-frequency and common genetic variation in ischemic stroke: The METASTROKE collaboration}

In the article "Low-frequency and common genetic variation in ischemic stroke: The METASTROKE collaboration" by R. Malik et al., ${ }^{1}$ there was an omission under Study Funding. The sentence after "Control data were obtained through the database of genotypes and phenotypes (dbGAP) maintained and supported by the United States National Center for Biotechnology Information, US National Library of Medicine" should read: "Control data for comparison with VISP stroke cases were from the dbGaP study High Density SNP Association Analysis of Melanoma: Case-Control and Outcomes Investigation (phs000187.v1.p1; R01CA100264, 3P50CA093459, 5P50CA097007, 5R01ES011740, 5R01CA133996, HHSN268200782096C; PIs Christopher Amos, Qingyi Wei, Jeffrey E. Lee).” The authors regret the omission.

\section{REFERENCE}

1. Malik R, Traylor M, Pulit SL, et al. Low-frequency and common genetic variation in ischemic stroke: The METASTROKE collaboration. Neurology 2016;86:1217-1226. 


\title{
Neurology
}

\section{Low-frequency and common genetic variation in ischemic stroke: The METASTROKE collaboration \\ Neurology 2016;87;1306 \\ DOI 10.1212/WNL.0000000000003193}

This information is current as of September 19, 2016

\author{
Updated Information \& \\ Services \\ including high resolution figures, can be found at: \\ http://n.neurology.org/content/87/12/1306.full \\ References \\ This article cites 1 articles, 1 of which you can access for free at: \\ http://n.neurology.org/content/87/12/1306.full\#ref-list-1 \\ Permissions \& Licensing \\ Information about reproducing this article in parts (figures,tables) or in \\ its entirety can be found online at: \\ http://www.neurology.org/about/about_the_journal\#permissions \\ Reprints Information about ordering reprints can be found online: \\ http://n.neurology.org/subscribers/advertise
}

Neurology ${ }^{\circledR}$ is the official journal of the American Academy of Neurology. Published continuously since 1951 , it is now a weekly with 48 issues per year. Copyright (C 2016 American Academy of Neurology. All rights reserved. Print ISSN: 0028-3878. Online ISSN: 1526-632X.

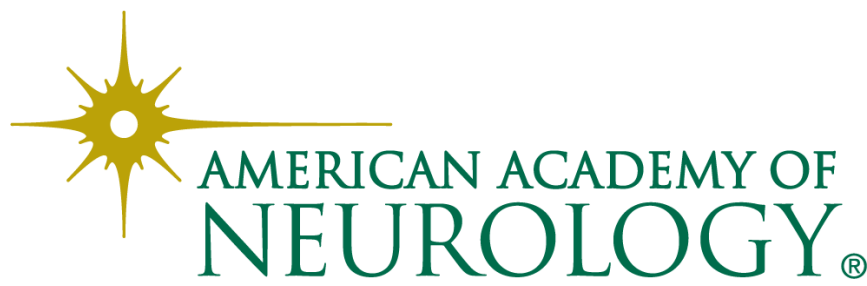

